\title{
Initial antimicrobial treatment of hospital acquired pneumonia in adults: A conference report
}

\section{The Canadian Hospital Acquired Pneumonia Consensus Conference Group}

$\mathrm{N}$ OSOCOMIAL OR HOSPITAL ACQUIRED PNEUMONIA IS A serious and potentially fatal illness. It is generally defined as pneumonia that develops $48 \mathrm{~h}$ or more after admission to hospital; of all hospital acquired infections, it is the second most common but is responsible for the highest mortality rates from nosocomial infection $(1,2)$. In a Canadian study, the overall mortality rate of hospital acquired pneumonia was $32 \%$; $28 \%$ for nonintensive care unit patients and $39 \%$ for those in an intensive care unit (2).

Since nosocomial pneumonia is not a reportable disease in Canada, it is difficult to obtain accurate statistics on its true incidence. Figures are quite variable and range from five to 50 cases per 1000 admissions (3). Overall, nosocomial pneumonia rates for a Canadian tertiary care hospital are 9.5 per 1000 admissions. However, these figures vary greatly depending upon the individual service. Selected incidence figures per 1000 discharges are: gynecology, 2.5; general surgery, 5.8; surgical intensive care, 48.0; and medical intensive care, $67.0(2)$.

Data on selected subgroups of patients with nosocomial pneumonia show that those who are bacteremic have the highest mortality rates, ranging from 48 to $58 \%$ (4) while mortality for infections caused by Pseudomonas aeruginosa may reach $70 \%$ (5). Studies of attributable mortality confirm the negative impact of nosocomial pneumonia on patient survival $(6,7)$.

\section{DEVELOPMENT OF GUIDELINES}

Despite the seriousness of nosocomial pneumonia and its attendant sequelae, treatment is at times inadequate. This is usually due to a lack of appreciation of the likely pathogens, and the influence of risk factors in the individual patient. To develop a standardized approach to the initial antimicrobial treatment of hospital acquired pneumonia in Canada, a meeting was held in Toronto, Ontario in December 1992. The participants included specialists in infectious diseases, microbiology, respiratory medicine, intensive care medicine and surgery. Physicians from Canada, the United States and the United Kingdom took part, and the guidelines presented in this paper are a representation of the opinions of these experts.

The purpose of these guidelines is to help the practising physician in the choice of initial antimicrobial management of patients with hospital acquired pneumonia. These guide-

Chairmen of Working Groups: Dr LA Mandell and Dr T Marrie

Other participants: Dr J Bass Jr, Dr A Chow, Dr D Craven, Dr R Finch, Dr K Forward, Dr R Grossman, Dr D Low, Dr L Nicolle,

Dr M Niederman, Dr D Phaneuf, Dr R Saginur, Dr G Sarosi, Dr S Shafran, Dr C Thornsberry, Dr T Todd, Dr R Wise, Dr V Yu

The Consensus Conference was supported by an educational grant from Glaxo Canada Inc

Correspondence and reprints: Dr Lionel A Mandell, McMaster Medical Unit, Henderson General Hospital, 711 Concession Street, Hamilton, Ontario L8V IC3. Telephone (905) 574-8520, Fax (905) 575-7320

Reproduced from Can J Infect Dis 1993;4:317-21 
TABLE 1

Initial treatment options for hospital acquired pneumonia Clinical presentation - mild to moderate; risk factors present

\begin{tabular}{|c|c|c|c|}
\hline Risks & Organisms & Drugs & \\
\hline $\begin{array}{l}\text { Gross aspiration } \\
\text { Thoraco-abdominal surgery }\end{array}$ & $\begin{array}{l}\text { Core organisms } \\
+ \\
+ \\
\text { anaerobes }\end{array}$ & $\begin{array}{l}\text { Cefazolin + gentamicin } \\
\text { Second generation cephalosporin } \\
\text { Nonpseudomonas third generation } \\
\text { cephalosporin } \\
\text { Ciprofloxacin } \\
\quad \text { or } \\
\text { Ticarcillin-clavulanic acid }\end{array}$ & $\begin{array}{l} \pm \text { Clindamycin } \\
\text { or } \\
\text { metronidazole }\end{array}$ \\
\hline $\begin{array}{l}\text { Diabetes } \\
\text { Coma } \\
\text { Head injury }\end{array}$ & $\begin{array}{c}\text { Core organisms } \\
\stackrel{+}{\text { Staphylococcus aureus }^{\ddagger}}\end{array}$ & $\begin{array}{l}\text { Cefazolin + gentamicin } \\
\text { Second generation cephalosporin } \\
\text { Nonpseudomonas third generation } \\
\text { cephalosporin } \\
\text { Ciprofloxacin }\end{array}$ & \\
\hline $\begin{array}{l}\text { Prolonged hospitalization } \\
\quad \text { and/or } \\
\text { Prior antibiotics } \\
\quad \text { and/or } \\
\text { ICU admission }\end{array}$ & $\begin{array}{l}\text { Core organisms (consider possible } \\
\text { resistant Gram-negative rods and } \\
\text { Pseudomonas aeruginosa) }\end{array}$ & See Table 3 & \\
\hline High dose corticosteroids & $\begin{array}{c}\text { Core organisms } \\
+ \\
\text { legionella }\end{array}$ & $\begin{array}{l}\text { Cefazolin + gentamicin } \\
\text { Second generation cephalosporin } \\
\text { Nonpseudomonas third generation } \\
\text { cephalosporin } \\
\text { Ciprofloxacin }\end{array}$ & + Macrolide \\
\hline Combination of risks & & See Table 3 (severely ill) & \\
\hline
\end{tabular}

ICU Intensive care unit; *Core organisms are listed in Table $2{ }^{\dagger}{ }^{\dagger}$ If the likely pathogen is an Enterobacter species, a cephalosporin should not be used regardless of in vitro susceptibility results; ${ }^{\ddagger}$ If methicillin-resistant $\mathrm{S}$ aureus is prevalent in your institution, consider adding vancomycin

\section{TABLE 2}

Initial treatment options for hospital acquired pneumonia Clinical presentation - mild to moderate; no unusual risk factors

\begin{tabular}{|c|c|c|}
\hline \multirow[b]{2}{*}{ Organisms ${ }^{*}$} & \multicolumn{2}{|c|}{ Drugs } \\
\hline & Intravenous & Orally \\
\hline $\begin{array}{l}\text { Klebsiella species } \\
\text { Enterobacter species }^{\dagger} \\
\text { Escherichia coli } \\
\text { Proteus species }\end{array}$ & $\begin{array}{l}\text { Cefazolin + gentamicin } \\
\text { Second generation cephalosporin } \\
\text { Nonpseudomanas third generation } \\
\text { cephalosporin }\end{array}$ & $\begin{array}{l}\text { Amoxicillin-clavulanic acid } \\
\text { Second generation cephalosporin } \\
\text { Trimethoprim-sulfamethoxazole } \\
\text { Fluoroquinolone }\end{array}$ \\
\hline
\end{tabular}

Staphylococcus aureus

With beta-lactam allergy, use ciprofloxacin or trimethoprim-sulfamethoxazole; *These represent the core organisms; ${ }^{\dagger}$ If the likely pathogen is an Enterobacter species, a cephalosporin should not be used regardless of in vitro susceptibility results

lines are not meant to deal with all situations, nor are they meant to be definitive. Their express purpose is solely to provide a rational approach to the initial antimicrobial treatment of hospital acquired pneumonia, and they are based upon careful consideration of various etiological, epidemiological and pathogenetic factors. The overriding concern in all cases is for the well-being and safety of the patient.

For these guidelines to be useful and workable, it was felt that they must be kept as practical, simple and user-friendly as possible. Had every clinical scenario been addressed, the guidelines would have become too cumbersome and complex and would soon be discarded. Accordingly, issues of pneumonia in severely immunocompromised patients such as those with organ transplants, neutropenic patients or human immunodeficiency virus-infected patients have specifically not been addressed, nor is tuberculosis considered. In Canada, such patients are often managed by physicians with specific expertise in these areas.

\section{APPROACH TO PNEUMONIA}

Nosocomial pneumonia may be approached in a number of ways, each with its own particular advantages and disadvantages. In developing these guidelines, it was decided to focus on what were felt to be the variables most likely to have an impact upon the potential microbial pathogens as well as the patient's course and prognosis in hospital. The approach was based upon the following two variables:

- The severity of illness upon clinical presentation;

- The presence or absence of risk factors for specific microbial pathogens. 
TABLE 3

Initial treatment options

Clinical presentation - severe

\begin{tabular}{ll}
\hline Organisms & Pseudomonas aeruginosa \\
& Klebsiella species \\
& Enterobacter species \\
& Escherichia coli \\
& Proteus species \\
& Serratia marcescens \\
& Staphylococcus aureus ${ }^{\star}$ \\
& Legionella pneumophila $^{\dagger}$ \\
& Intravenous \\
& Broad spectrum beta-lactam or fluoroquinolone with \\
Drugs & activity against $P$ aeruginosa \\
& Piperacillin \\
& Ceftazidime \\
& Imipenem/cilastatin \\
& Ticarcillin/clavulanic acid \\
& Ciprofloxacin \\
\hline
\end{tabular}

*If methicillin-resistant $\mathrm{S}$ aureus is prevalent in your institution, consider adding vancomycin; ${ }^{\dagger}$ May be a nosocomial pathogen. If so, add a macrolide; ${ }^{\ddagger}$ Other combinations may be considered, eg, ceftazidime/ ciprofloxacin

There are very few published studies that specifically define severity of illness for nosocomial pneumonia. Therefore, it was decided to extrapolate from data on community acquired pneumonia, and the following have been selected as criteria for 'severe pneumonia'. A number of these features have been identified in a study of risk and prognosis in patients with nosocomial pneumonia (8). Patients may be considered to be severely ill if they present with any of the following: respiratory failure $\left(\mathrm{PaO}_{2}\right.$ less than $60 \mathrm{mmHg}$ on an $\mathrm{FiO}_{2}$ over $35 \%$, with the exception of patients with chronic obstructive airway disease, who may be hypoxemic without pneumonia), respiratory rate $30 / \mathrm{min}$ or greater, sepsis with evidence of end organ dysfunction (severe sepsis), extrapulmonary septic complications, cavitation or involvement of more than one lobe on chest radiograph (9-11). For practical purposes, it is best to consider any patient with pneumonia who is being mechanically ventilated as having a severe infection.

It is clear from the literature and from clinical experience in general that certain events or procedures involving patients may act as risk factors for development of nosocomial pneumonia $(2,12-14)$. Some of these include previous antimicrobial therapy, surgery, hospitalization in an intensive care unit, and use of ventilatory support (2). Among specific subgroups of patients with nosocomial pneumonia, such as those having had prior surgery or patients receiving ventilatory support, additional risk factors have been identified. In the surgery group, such factors include longer preoperative stays in hospital and longer operative procedures, as well as thoracoabdominal surgery (12). In ventilated patients, additional risk factors include elevation of gastric $\mathrm{pH}$, mechanical ventilation for more than three days and more than one intubation during ventilation $(13,14)$.

For these guidelines, it was felt that the presence or absence of certain risk factors was critical to selection of initial antimicrobial management. Certain risk factors which might

\section{Appendix \\ Antibiotics for the treatment of hospital acquired pneumonia}

\begin{tabular}{|c|c|c|}
\hline \multicolumn{2}{|c|}{ Drug class } & \multirow{3}{*}{$\begin{array}{l}\text { Individual agents } \\
\text { Penicillin } \mathrm{G}^{\star \dagger}\end{array}$} \\
\hline \multirow[t]{15}{*}{ I. } & Beta-lactams & \\
\hline & a) Penicillins & \\
\hline & & Phenoxymethyl penicillin* \\
\hline & $\begin{array}{l}\text { b) Anti-pseudomonal } \\
\text { penicillins }\end{array}$ & Piperacillin ${ }^{\dagger}$ \\
\hline & c) Penicillins + beta- & Amoxicillin-clavulanic acid ${ }^{*}$ \\
\hline & lactamase inhibitors & Ticarcillin-clavulanic acid ${ }^{\dagger}$ \\
\hline & d) Cephalosporins & \\
\hline & First generation & Cefazolin $^{\dagger}$ \\
\hline & Second generation & Cefuroxime $^{* \dagger}$ \\
\hline & & Cefamandol $^{\dagger}$ \\
\hline & Nonpseudomonas third & Ceftriaxone $^{\dagger}$ \\
\hline & generation & Cefotaxime $^{\dagger}$ \\
\hline & Third generation with & Ceftazidime $^{\dagger}$ \\
\hline & $\begin{array}{l}\text { anti-pseudomonas } \\
\text { activity }\end{array}$ & \\
\hline & e) Carbapenem & Imipenem/cilastatin $^{\dagger}$ \\
\hline \multirow[t]{2}{*}{11.} & Macrolides & Erythromycin* ${ }^{\star}$ \\
\hline & & Clarithromycin* \\
\hline III. & Lincosamides & Clindamycin* ${ }^{\dagger}$ \\
\hline \multirow[t]{2}{*}{ IV. } & Fluoroquinolones & Ciprofloxacin $^{\star}{ }^{\dagger}$ \\
\hline & & Ofloxacin* \\
\hline \multirow[t]{4}{*}{ V. } & Aminoglycosides & Gentamicin $^{\dagger}$ \\
\hline & & Tobramycin $^{\dagger}$ \\
\hline & & Amikacin $^{\dagger}$ \\
\hline & & Netilmicin ${ }^{\dagger}$ \\
\hline \multirow[t]{3}{*}{ VI. } & Miscellaneous & Trimethoprim- \\
\hline & & sulfamethoxazole* ${ }^{\dagger}$ \\
\hline & & Vancomycin $^{\dagger}$ \\
\hline
\end{tabular}

${ }^{*}$ Orally; ${ }^{\dagger}$ Intravenous

predispose to nosocomial pneumonia associated with a particular pathogen(s) are presented in Table $1(15,16)$.

Certain patients may also require admission to the intensive care unit. While a detailed discussion of this is beyond the scope of this paper, the following may serve as a guide. The presence of one or more of the following should be considered as a criterion for admission to the intensive care unit.

- Arterial oxygen saturation less than $90 \%$ on an $\mathrm{FiO}_{2}$ of 0.5 using ventimask. In some patients, this may be preceded by rapid chest radiographic and arterial blood gas deterioration;

- Requirement for acute mechanical ventilation;

- Requirement for frequent chest physiotherapy and nursing supervision;

- Hypotension requiring inotropic support.

Basing the approach upon severity of illness and presence or absence of selected risk factors allows a flexible yet broad approach to initial treatment of hospital acquired pneumonia. It should be understood that these guidelines are meant only as an aid to the physician, and in all cases the individual physician dealing with pneumonia in a particular patient is ultimately in the best position to determine ideal therapy. Knowledge of the individual patient and of institutionspecific microbial epidemiology and resistance patterns should be used to modify these guidelines whenever necessary or appropriate. 


\section{DIAGNOSTIC ISSUES}

The etiological pathogens responsible for nosocomial pneumonia differ substantially from those which cause community acquired pneumonia. Organisms such as Streptococcus pneumoniae, Mycoplasma pneumoniae and Chlamydia pneumoniae are frequent pathogens in community acquired pneumonia while aerobic Gram-negative rods and Staphylococcus aureus account for the majority of hospital acquired pneumonia cases $(2,17)$. In patients who have impaired consciousness or other neurological conditions which might predispose to aspiration, anaerobes should also be considered as potential pathogens.

Depending on the method used to determine microbial etiology, results may vary from study to study. Using the protected specimen brush, sputum cultures or blood cultures, however, Gram-negative organisms account for 61 to $75 \%$ of pathogens and S aureus for 22 to 33\% (2). Of the Gram-negative pathogens, $P$ aeruginosa is the single most common organism, particularly in ventilated patients (2). Specific organisms that may be associated with particular risk factors are listed in Table 1.

The diagnosis of nosocomial pneumonia requires the synthesis of information obtained from a careful history, physical examination and appropriate laboratory tests and/or procedures. The history should identify any comorbid conditions and risk factors. The physician must also be careful to consider any noninfectious causes of fever and pulmonary infiltrates that may confound the picture. If possible, a good quality expectorated or suctioned sputum sample for Gram stain and culture should be obtained. Invasive procedures such as bronchoscopy are not usually necessary for most cases during the initial evaluation. Blood should be drawn for determination of a complete blood count and differential, and two sets of blood cultures should be collected as well. Routine radiological examination should include a posteroanterior and lateral chest radiograph. In patients who are intubated, a more aggressive approach to diagnosis may be necessary. In such cases, where expertise exists, use of both protected specimen brush technique and bronchoalveolar lavage (BAL) are options to be considered (18). Gram stain of centrifuged BAL fluid may then be used as a guide to initial empirical antibiotic therapy (18).

\section{THERAPEUTIC ISSUES}

In selecting drugs to be used for the treatment of hospital acquired pneumonia, a number of issues have been considered. Clearly, the severity of illness and the presence or absence of certain risk factors have influenced what are thought to be the likely pathogens and the suggested initial treatment. Activity and pharmacokinetic properties of antimicrobial agents and any other factors which might be of importance for the treatment of hospital acquired pneumonia were also considered. Options for initial oral therapy of mild cases are included as well.

Two issues in particular should be mentioned. In treating severely ill patients, concern about infection with $P$ aeruginosa assumed prominence. Since mortality associated with this infection is considerably higher than is seen with other bacterial pneumonias, it was felt that treatment should be particularly aggressive $(19,20)$. Data suggest that improved efficacy can be realized with combination therapy as opposed to single agent treatment of this condition, particularly if bacteremia is present $(21,22)$.

There is also some concern about the use of aminoglycosides alone for the treatment of hospital acquired pneumonia. Since these drugs penetrate poorly into infected airways and may be inactivated by the low $\mathrm{pH}$ of secretions found in infected airways, it was felt they should not be the sole agent relied upon for the treatment of Gram-negative bacillary lung infections $(23,24)$.

Based upon the variables discussed above, the various treatment options are presented in Tables 1, 2 and 3. Wherever possible, we have used classes of drugs rather than individual agents (Appendix). However, if only one drug in a given class was available or considered suitable, then that specific drug name has been used. Tables 1 and 2 deal with patients with mild to moderate infections who have either no unusual risk factors (Table 2) or in whom risk factors for specific pathogens may be present (Table 1). Table 3 deals with patients with severe hospital acquired pneumonia.

In all cases, whenever additional information such as culture and susceptibility data that may affect treatment become available, the attending physician should amend or modify the initial regimen as necessary. Attention must also be paid to supportive treatment including management of fluid and electrolyte balance, oxygenation and management of any complications that might arise.

\section{REFERENCES}

1. Horan TC, White JW, Jarvis WR, et al. Nosocomial infection surveillance. MMWR CDC Surveill Summ 1986;35:17SS-29SS.

2. Johnston BL, Forward K, Marrie TJ. Nosocomial pneumonia. Chest Surg Clin North Am 1991;1:337-68.

3. Pugliese G, Lichtenberg DA. Nosocomial bacterial pneumonia: An overview. Am J Infect Control 1987;15:249-65.

4. Leu HS, Kaiser DL, Mori M, et al. Hospital-acquired pneumonia: Attributable mortality and morbidity. Am J Epidemiol 1989;129:1258-67.

5. Craven DE, Kunches LM, Lichtenberg DA, et al. Nosocomial infection and fatality in medical and surgical intensive care unit patients. Arch Intern Med 1988;148:1161-8.

6. Fagon J-Y, Chastre J, Hance AJ, Montravers P, Novara A. Gilbert C. Nosocomial pneumonia in ventilated patients: A cohort study evaluating attributable mortality and hospital stay. Am J Med 1993;94:281-8.

7. Leu H-S, Kaiser DL, Mori M, Woolson RF, Wenzel RP. Hospital-acquired pneumonia. Attributable mortality and morbidity. Am J Epidemiol 1989;129:1258-67.

8. Celis R, Torrs A, Gatell JM, et al. Nosocomial pneumonia. A multivariate analysis of risk and prognosis. Chest 1988;93:318-24.

9. Pachon J, Prados D, Capote F, Cuello JA, Garnacho J, Verano A. Severe community-acquired pneumonia. Etiology, prognosis, and treatment. Am Rev Respir Dis 1990;142:369-73.

10. Farr BM, Sloman AJ, Fisch MJ. Predicting death in patients hospitalized for community-acquired pneumonia. Ann Intern Med 1991;115:428-36.

11. Torres A, Serra-Batlles J, Ferrer A, et al. Severe 
community-acquired pneumonia. Epidemiology and prognostic factors. Am Rev Respir Dis 1991;144:312-8.

12. Haley RW, Hooten TM, Culver D, et al. Nosocomial infections in US Hospitals, 1975-1976: Estimated frequency by selected characteristics of patients. Am J Med 1981;70:947-59.

13. Craven DE, Kunches LM, Kilinsky V, et al. Risk factors for pneumonia and fatality in patients receiving continuous mechanical ventilation. Am Rev Respir Dis 1986;133:792-6.

14. Torres A, Aznar R, Gatell JM, et al. Incidence, risk, and prognostic factors of nosocomial pneumonia in mechanically ventilated patients. Am Rev Respir Dis 1990;142:523-8.

1.5. Rello J, Ausina V, Castella J, Net A, Prats G. Nosocomial respiratory tract infections in multiple trauma patients. Influence of level of consciousness with implications for therapy. Chest 1992;102:525-9.

16. Fagon J-Y, Chastre J, Domart Y, et al. Nosocomial pneumonia in patients receiving continuous mechanical ventilation. Am Rev Respir Dis 1989;139;877-84.

17. Gross PA. Epidemiology of hospital-acquired pneumonia. Semin Respir Infect 1987;2:2-7.
18. Chastre J, Fagon JY, Gilbert DC. Diagnosis of nosocomial pneumonia in intensive care units. Eur J Clin Microbiol Infect Dis 1989;8:35-9.

19. Stevens RM, Teres D, Skillmann JJ, et al. Pneumonia in an intensive care unit: A 30-month experience. Arch Intern Med 1974;134:106-11.

20. Bryan CS, Reynolds KL. Bacteremic nosocomial pneumonia. Analysis of 172 episodes from a single metropolitan area. Am Rev Respir Dis 1984;129:668-71.

21. Pennington JE. New therapeutic approaches to hospitalacquired pneumonia. Semin Respir Infect 1987;2:67-73.

22. Hilf M, Yu VL, Sharp J, Zuravleff JJ, Korvick JA, Muder RR. Antibiotic therapy for Pseudomonas aeruginosa bacteremia: Outcome correlations in a prospective study of 200 patients. Am J Med 1989;87:540-6.

23. Pennington JE. Penetration of antibiotics into respiratory secretions. Rev Infect Dis 1981:3:67-73.

24. Bodem CR, Lampton LM, Miller DP, et al. Endobronchial pH. Relevance to aminoglycoside activity in Gram-negative bacillary pneumonia. Am Rev Respir Dis 1983;127:39-41. 


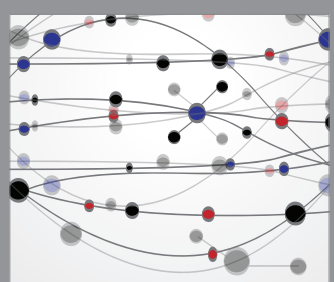

The Scientific World Journal
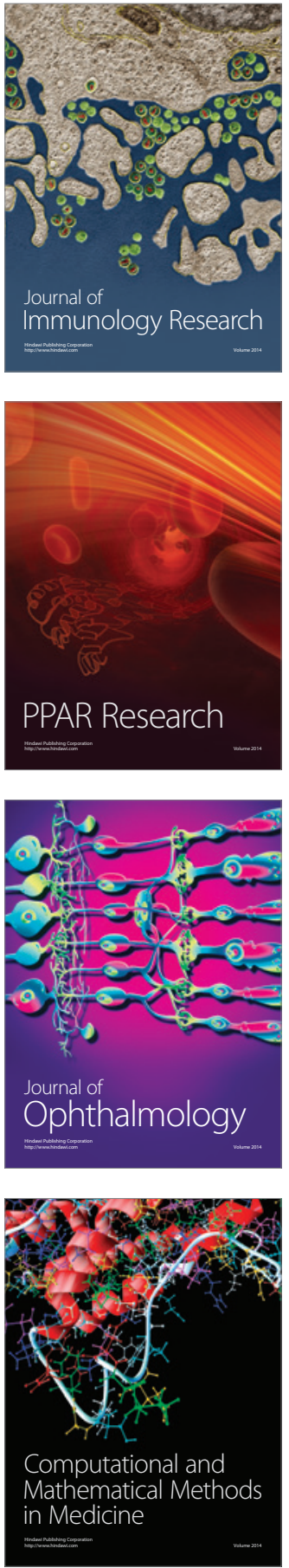

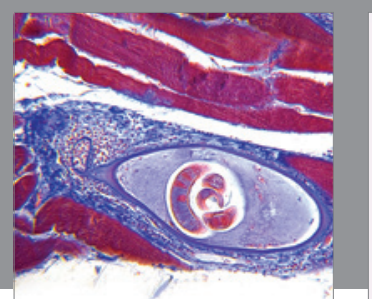

Gastroenterology Research and Practice

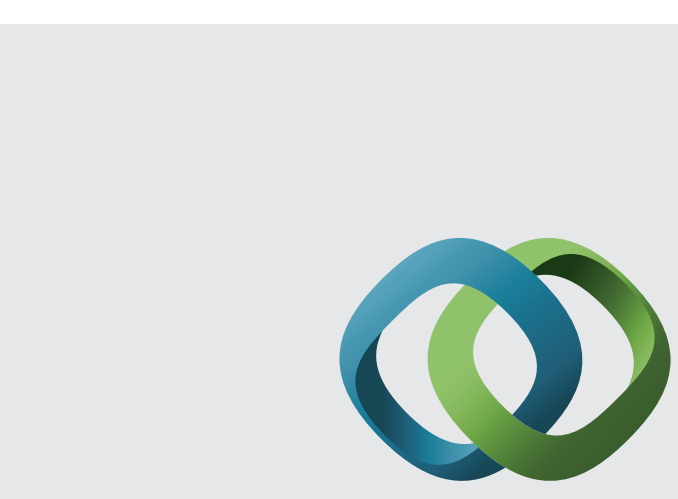

\section{Hindawi}

Submit your manuscripts at

http://www.hindawi.com
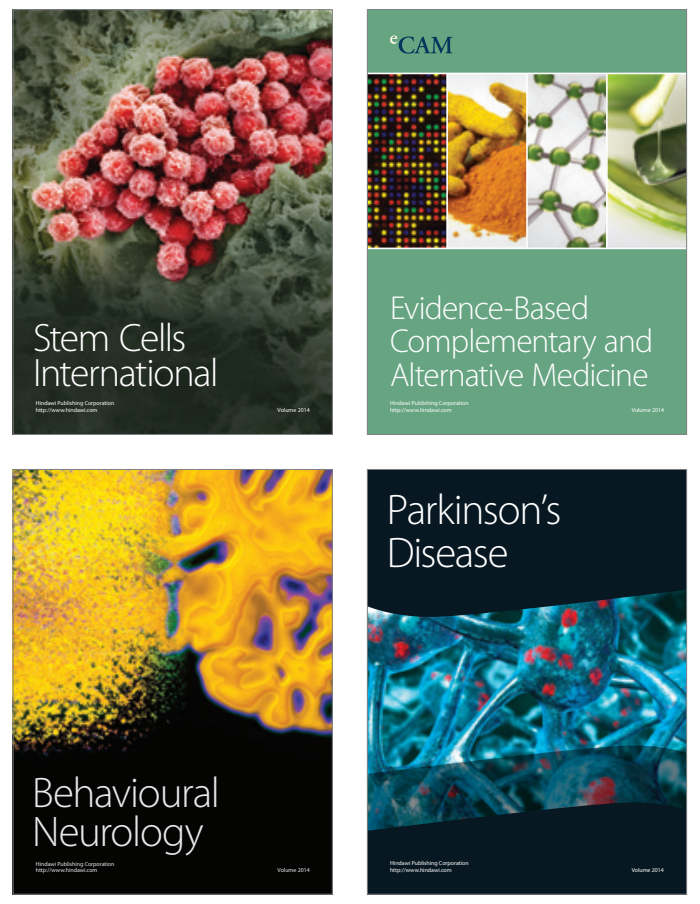
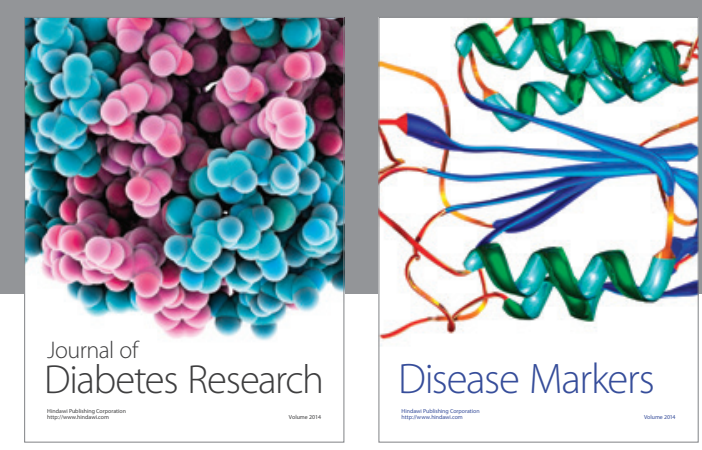

Disease Markers
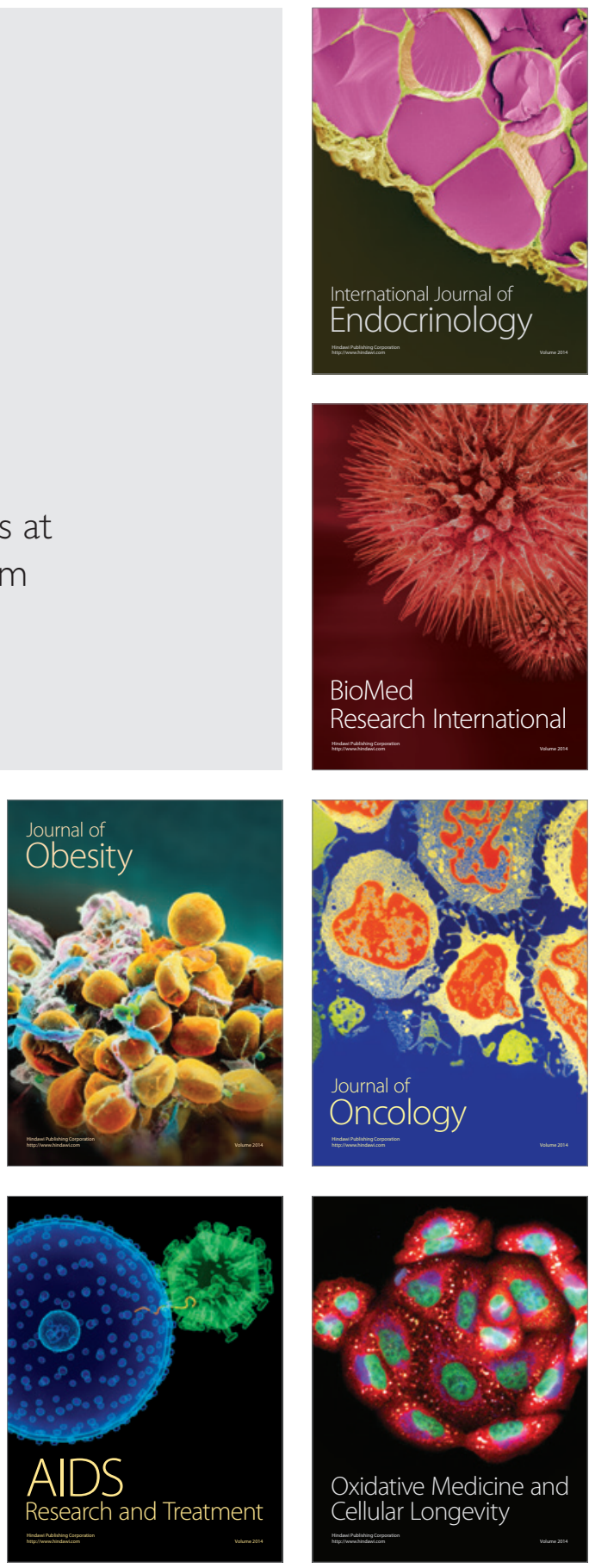